\title{
ANALISIS PENERAPAN PAJAK PENGHASILAN PASAL 21 PADA CV UNGGUL ABADI DI MANADO
}

\author{
Winesthy Anasthazia Handaputri Alfons ${ }^{1}$, Treesje Runtu ${ }^{2}$, Dhullo Afandi ${ }^{3}$ \\ ${ }^{1,2,3}$ Fakultas Ekonomi dan Bisnis, Jurusan Akuntansi, Universitas Sam Ratulangi, Jl.Kampus Bahu, Manado, \\ 95115, Indonesia \\ E-mail : awinesthy@gmail.com
}

\begin{abstract}
Contribution of tax income year to year always shows a significant augmentation together with the augmentation of APBN for year to year. Tax is an important source of state's income to run and to increase the national development for the people's welfare and wealthy. The aim of this research is to analyse whether the application of determination, depositing and reporting of Income Tax Chapter 21 in CV Unggul Abadi in Manado has already met the rule of taxing. In this research the data used is qualificative, while the data source uses primary data and secondary data. The method of analyse used is descriptive analyse method. The result of the research concludes that determining, estimating, depositing and reporting Tax Income Chapter 21 in CV Unggul Abadi has not met the newest tax rule yet.
\end{abstract}

Keywords: Tax Income Chapter 21, APBN, state's income

\section{PENDAHULUAN}

Pajak merupakan sumber pendapatan atau penerimaan Negara yang sangat penting bagi pelaksanaan dan peningkatan pembangunan nasional untuk mencapai kemakmuran dan kesejahteraan rakyat. Pajak merupakan salah satu sumber pendapatan yang dipungut berdasarkan undang-undang. Pajak berfungsi sebagai pengeluaran-pengeluaran pemerintah dalam mengatur dan melaksanakan segala kebijakan pemerintah dalam pembangunan sarana dan prasarana di bidang ekonomi.

Salah satu jenis pajak yang dikenal di Indonesia saat ini adalah pajak penghasilan $(\mathrm{PPh})$ yang dikenakan terhadap subjek pajak atas penghasilan yang diterima atau diperolehnya dalam tahun pajak. Pajak penghasilan dikenakan atas penghasilan baik yang diperoleh orang pribadi, warisan yang belum terbagi dan badan maupun Bentuk Usaha Tetap (BUT) yang memperoleh penghasilan di Indonesia. PPh pasal 21 merupakan pajak penghasilan atas penghasilan objek pajak seperti gaji, upah, honorarium, tunjangan serta pembayaran lainnya dengan nama apapun sehubungan dengan pekerjaan, jasa atau kegiatan yang dilakukan oleh wajib pajak pribadi dalam negeri.

CV Unggul Abadi merupakan perusahaan yang bergerak dibidang kontraktor. Setiap kegiatan usaha perusahaan ini tentunya tidak terlepas dari kewajiban perpajakan atas penghasilan yang diperoleh oleh perusahaan dari kegiatan operasinya. Sebagai perusahaan yang taat akan pembayaran pajak maka, CV Unggul Abadi berkewajiban untuk melakukan pelaporan pajak penghasilan sesuai ketentuan yang mengacu pada Undang-Undang Pajak Penghasilan Pasal 21.

\section{TINJAUAN PUSTAKA}

\subsection{Konsep Akuntansi}

\subsubsection{Definisi Akuntansi}

Akuntansi merupakan aktivitas mengumpulkan, menganalisis, menyajikan dalam bentuk angka, mengklasifikasikan, mencatat, meringkas serta melaporkan aktivitas atau transaksi suatu badan usaha dalam bentuk informasi keuangan (Rudianto, 2012). 


\subsection{Pengertian Perpajakan}

Untuk lebih memahami perpajakan, terlebih dahulu perlu memahami pengertian pajak. Banyak ahli yang memberikan definisi tentang pajak. Berikut ini diberikan beberapa definisi pajak menurut para ahli dari berbagai sudut pandang yang berbeda.

Menurut S. I. Djajadiningrat (2013), Pajak sebagai suatu kewajiban menyerahkan sebagian dari kekayaan ke kas Negara yang disebabkan suatu keadaan, kejadian dan perbuatan yang memberikan kedudukan tertentu, tetapi bukan sebagai hukuman, menurut peraturan yang telah ditetapkan oleh pemerintah dapat dipaksakan, namun tidak ada jasa timbal balik dari Negara secara langsung untuk memelihara kesejahteraan secara umum.

\subsection{Fungsi Pajak}

Menurut Mardiasmo (2016), ada dua fungsi pajak yaitu Fungsi Anggaran (Budgetair) dan Fungsi Mengatur (Reguleren).

\subsection{Tata Cara Pemungutan Pajak}

Menurut Mardiasmo (2016:8), tata cara pemungutan pajak dapat dibedakan menjadi

1. Stelsel Pajak

Pemungutan pajak dilakukan berdasarkan 3 stelsel:
a. Steltel nyata (rill stestel)
b. Steltel anggapan (fictieve steltel)
c. Steltel Campuran

2. Sistem Pemungutan Pajak

Sistem pemungutan pajak dapat dibagi menjadi :
a. Official Assesment System
b. Self Assisment System
c. Witholding System

3. Asas Pemungutan Pajak

Asas Pemungutan Pajak dapat dibagi menjadi :
a. Asas domisili (Asas tempat tinggal)
b. Asas Sumber
c. Asas Kebangsaan.
d. Pengenaan pajak dihubungkan dengan kebangsaan suatu Negara.

\subsection{Syarat Pemungutan Pajak}

Mardiasmo (2016:4), syarat pemungutan pajak agar pemungutan pajak tidak menimbulkan hambatan ataupun perlawanan, maka pemungutan pajak harus memenuhi syarat sebagai berikut :

1. Pemungutan Pajak harus adil (Syarat Keadilan)

2. Pemungutan pajak harus berdasarkan undang-undang (Syarat Yuridis).

3. Tidak menganggu perekonomian (Syarat Ekonomis).

4. Pemungutan pajak harus efisien (Syarat Finansial).

5. Sistem pemungutannya harus sederhana.

\subsection{Pengelompokkan Pajak}

Pajak digolongkan dalam beberapa jenis, dimana seluruhnya sangat berperan penting bagi pembangunan nasional. Pengelompokkan itu antara lain didasarkan pada pajak menurut golongan, lembaga pemungut dan sifatnya. Berikut adalah pengelompokkan pajak menurut Mardiasmo (2016:7), yaitu :

1. Berdasarkan golongannya:

Pajak langsung dan Pajak tidak langsung

2. Berdasarkan lembaga pemungutannya:

Pajak Negara/Pusat dan Pajak Daerah

3. Menurut sifatnya :

Pajak Subjektif dan Pajak Objektif 


\subsection{Tarif Pajak}

Menurut Mardiasmo (2016:11), ada 4 macam tarif pajak yaitu :

1. Tarif Sebanding/Proposional

Tarif persentase tetap terhadap berapapun jumlah yang dikenai pajak sehingga besarnya pajak yang terutang proposional terhadap besarnya nilai yang dikenai pajak.

2. Tarif Tetap

Tarif jumlah tetap terhadap berapapun jumlah yang dikenai pajak sehingga besarnya pajak yang terutang tetap.

3. Tarif Progresif

Persentase tarif yang digunakan semakin besar bila jumlah yang dikenai pajak semakin besar.

4. Tarif Degresif

Persentase tarif yang digunakan semakin kecil bila jumlah yang dikenai pajak semakin besar.

\subsection{Pajak Penghasilan}

\subsubsection{Pengertian Pajak Penghasilan}

Sesuai dengan sebutannya pajak penghasilan itu dikenakan atas penghasilan. Pajak penghasilan merupakan salah satu jenis pajak pusat yang objeknya adalah penghasilan. Pajak penghasilan dikenakan terhadap wajib pajak yaitu apabila telah terpenuhi syarat subjektif dan syarat objektif sebagaimana yang telah ditetapkan dalam Undang-Undang Pajak Penghasilan.

Berdasarkan UU No. 36 Tahun 2008, Pengenaan PPh terhadap subjek pajak berkenaan dengan penghasilan yang diterima dalam tahun pajak. Subjek pajak tersebut dikenai pajak jika menerima penghasilan, dalam Undang-Undang ini disebut Wajib Pajak.

\subsubsection{Subjek Pajak Penghasilan}

Menurut UU No. 36 Tahun 2008 Pasal 2 Ayat 1 yang menjadi subjek pajak penghasilan adalah sebagai berikut:

1. Subjek Pajak Orang Pribadi

2. Subjek Pajak harta warisan belum dibagi.

3. Subjek Pajak Badan

4. Bentuk Usaha Tetap.

\subsubsection{Tidak Termasuk Subjek Pajak}

Menurut Undang-Undang Nomor 3 Tahun 2008 Pasal 3 menjelaskan tentang apa yang tidak termasuk subjek pajak sebagai berikut:

1. Badan perwakilan Negara asing

2. Pejabat perwakilan diplomatic dan konsultan atau pejabat-pejabat yang diperbantukan kepada mereka yang bekerja pada dan bertempat tinggal bersama mereka dengan syarat bukan warga Negara Indonesia perlakuan timbal balik.

3. Organisasi internasional yang ditetapkan oleh keputusan menteri keuangan dengan syarat Indonesia ikut dalam organisasi tersebut.

4. Pejabat perwakilan organisasi internasional yang ditetapkan oleh keputusan menteri keuangan dengan syarat bukan warga Negara Indonesia.

\subsubsection{Objek Pajak Penghasilan}

Tambahan kemampuan ekonomis yang diterima atau diperoleh Wajib Pajak baik berasal dari Indonesia maupun dari luar Indonesia merupakan penghasilan dari objek pajak, yang dapat dipakai untuk konsumsi atau untuk meningkatkan aset dari wajib pajak yang bersangkutan dengan nama dan dalam bentuk apapun.

\subsubsection{Tidak Termasuk Objek Pajak Penghasilan}

Berdasarkan Pasal 4 Ayat 3 Undang-Undang Nomor 36 Tahun 2008 yang tidak termasuk menjadi objek pajak penghasilan adalah sebagai berikut : 
1. Bantuan sumbangan, yaitu zakat yang diterima oleh badan amil zakat atau lembaga amil zakat yang dibentuk atau disahkan oleh pemerintah dan para penerima zakat yang berhak.

2. Keluarga dalam garis keturunan lurus satu derajat yang menerima harta hibahan, dan oleh badan keagamaan atau badan pendidikan atau badan sosial atau pengusaha kecil termasuk koperasi yang ditetapkan oleh Menteri Keuangan.

3. Warisan.

\subsection{Penghasilan Tidak Kena Pajak (PTKP)}

Besarnya PTKP di Indonesia sudah mengalami beberapa kali perubahan, ini merupakan kronologis perubahan tersebut :

\section{Tabel 2.2}

Kronologis Perubahan Besarnya PTKP

\begin{tabular}{|c|r|r|c|}
\hline & \multicolumn{3}{|c|}{ Besarnya PTKP untuk tahun pajak (Rp) } \\
\cline { 2 - 4 } & \multicolumn{1}{|c|}{2012} & \multicolumn{1}{c|}{2015} & \multicolumn{1}{c|}{2016} \\
\hline Untuk diri WP OP & 24.300 .000 & 36.000 .000 & 54.000 .0000 \\
\hline Tambahan WP Kawin & 2.025 .000 & 3.000 .000 & 4.500 .000 \\
\hline Tambahan istri bekerja & 24.300 .000 & 36.000 .000 & 54.000 .0000 \\
\hline Tambahan tanggungan & 2.025 .000 & 3.000 .000 & 4.500 .000 \\
\hline
\end{tabular}

(sumber :http://www.pajak.go.id)

\subsection{Tarif Pajak Penghasilan}

Sesuai dengan pasal 17 ayat 1 UU No. 36 Tahun 2008, besarnya tarif pajak penghasilan adalah sebagai berikut :

1. Wajib Pajak orang pribadi dalam negeri dengan menggunakan tarif progresif

Tabel 2.3

WP Orang Pribadi dalam Negeri

\begin{tabular}{|l|c|}
\hline Lapisan Penghasilan Kena Pajak & Tarif Pajak \\
\hline Sampai dengan Rp. 50.000.000,00 & $5 \%$ \\
\hline Diatas Rp. 50.000.000,00 s.d Rp. 250.000.000,00 & $15 \%$ \\
\hline Diatas Rp. 250.000.000,00 s.d Rp. 500.000.000,00 & $25 \%$ \\
\hline Diatas Rp. 500.000.000,00 & $30 \%$ \\
\hline
\end{tabular}

(sumber: UU No. 36 tahun 2008 pasal 17 ayat 1)

2. Wajib Pajak badan dalam negeri dan Bentuk Usaha Tetap (BUT)

Sesuai dengan perubahan ketentuan Pasal 17 UU PPh tahun 2008 yang berlaku mulai tanggal 1 Januari 2009 :

Tabel 2.4

WAJIB PAJAK BENTUK USAHA TETAP

\begin{tabular}{|l|l|}
\hline Keterangan & Tarif Pajak \\
\hline Tahun 2009 & $28 \%$ \\
\hline Tahun 2010 dan seterusnya & $25 \%$ \\
\hline $\begin{array}{l}\text { Saham yang diperdagangkan di bursa efek } \\
\text { sebesar 40\% }\end{array}$ & $\begin{array}{l}5 \% \text { lebih rendah dari } \\
\text { yang seharusnya }\end{array}$ \\
\hline $\begin{array}{l}\text { Peredaran bruto sampai dengan Rp. } \\
50.000 .000 .000,-\end{array}$ & $\begin{array}{l}\text { Pengurangan 50\% dari } \\
\text { yang seharusnya }\end{array}$ \\
\hline
\end{tabular}




\subsection{Pajak Penghasilan Pasal 21}

\subsubsection{Pengertian Pajak Penghasilan Pasal 21}

Peraturan Direktorat Jenderal Pajak Nomor PER-16/PJ/2016 menggambarkan Pajak Penghasilan Pasal 21 merupakan pajak atas penghasilan berupa gaji, upah, honorarium, tunjangan dan pembayaran lain dengan nama dan dalam bentuk apapun sehubungan orang pribadi subjek pajak dalam negeri dengan pekerjaan atau jabatan, jasa dan kegiatan yangdilakukannya.

Menurut Diana Sari (2014:25), Pajak Penghasilan Pasal 21 adalah pajak penghasilan yang harus dipotong oleh setiap pemberi kerja terhadap imbalan berupa gaji, upah, honorarium, tunjangan, penghargaan maupun pembayaran lainnya yang mereka bayar atau terutang kepada orang pribadi dalam negeri sehubungan dengan pekerjaan jasa dan kegiatan yang dilakukan orang pribadi tersebut.

\subsubsection{Pemotong Pajak Penghasilan Pasal 21}

Pemotong Pajak Penghasilan Pasal 21 menurut Mardiasmo (2011), adalah: Pemberi kerja yang terdiri dari orang pribadi dan badan, baik merupakan pusat maupun cabang, perwakilan atau unit, bentuk usaha tetap, membayar gaji, honor dan pembayaran lain dengan nama apapun sebagai imbalan sehubungan deengan pekerjaan atau jasa yang dilakukan oleh pegawai atau bukan pegawai.

\subsubsection{Objek Pajak Penghasilan Pasal 21}

Berikut ini merupakan objek PPh Pasal 21 berdasarkan Peraturan Dirjen Pajak terbaru yaitu PER-16/PJ/2016 adalah sebagai berikut:

1. Penghasilan yang diterima oleh pegawai tetap, baik berupa Penghasilan yang bersifat teratur maupun tidak teratur.

2. Penghasilan yang diterima oleh penerima pension secara teratur berupa uang penghasilan sejenisnya.

3. Penghasilan yaitu uang pesangon, uang manfaat pension, tunjangan hari tua yang dibayarkan sekaligus yang pembayarannya melewati jangka waktu 2 tahun sejak pegawai berhenti bekerja..

Selain penghasilan yang dipotong PPh Pasal 21, berikut merupakan penghasilan yang bukan merupakan Objek PPh Pasal 21 berdasarkan Peraturan Dirjen Pajak terbaru PER16/PJ/2016, yaitu:

1. Pembayaran manfaat atau santunan asuransi dari perusahaan asuransi sehubungan dengan asuransi kesehatan, asuransi jiwa, asuransi kecelakaan dan asuransi lainnya.

2. Penerimaan dalam bentuk natura dan/atau kenikmatan dalam bentuk apapun yang diberikan oleh Wajib Pajak atau Pemerintah, kecuali penghasilan sebagaimana dimaksud dalam Pasal 5 ayat (2) yaitu yang diberikan oleh:

a. WP yang dikenakan PPh yang bersifat final; atau

b. WP yang dikenakan $\mathrm{PPh}$ berdasarkan norma perhitungan khusus (deemed profit)

\subsubsection{Perhitungan Pemotongan Pajak Penghasilan Pasal 21}

1. Perhitungan atas pegawai tetap

Pegawai tetap adalah pegawai yang menerima atau memperoleh penghasilan dalam jumlah tertentu secara teratur, termasuk anggota dewan komisaris dan anggota dewan pengawas yang secara teratur terus menerus ikut mengelola kegiatan perusahaan secara langsung, serta pegawai yang bekerja sesuai kontrak untuk suatu jangka waktu tertentu sepanjang pegawai yang bersangkutan bekerja penuh dalam pekerjaan tersebut.

2. Perhitungan atas pegawai tidak tetap 
Pegawai yang hanya menerima penghasilan apabila pegawai yang bersangkutan bekerja berdasarkan jumlah hari kerja, jumlah unit hasil pekerjaan yang dihasilkan atau penyelesaian suatu jenis pekerjaan diminta oleh pemberi kerja disebut dengan pegawai tidak tetap atau tenaga kerja lepas.

\subsubsection{Tatacara Penyetoran dan Pelaporan PPh Pasal 21}

Menurut Peraturan Direktorat Jenderal Pajak Nomor: PER-16/PJ/2016 mengenai tatacara penyetoran dan pelaporan PPh Pasal 21 adalah PPh Pasal 21 yang dipotong oleh pemotong PPh Pasal 21 untuk setiap masa pajak wajib disetor ke Kantor Pos atau bank yang ditunjuk oleh Menteri Keuangan paling lambat 10 (sepuluh) hari setelah masa pajak berakhir.

\section{METODE PENELITIAN}

\subsection{Jenis Penelitian}

Penelitian ini menggunakan penelitian kualitatif metode deskriptif analisis yaitu dengan pendekatan studi kasus yang bertujuan untuk memberikan gambaran mengenai keadaan perusahaan dengan melakukan kegiatan observasi atau wawancara. Menurut Clifford, et al (2013) penelitian kualitatif masuk dalam kategori desain penelitian deskriptif yang fokusnya adalah untuk menemukan apa yang terjadi pada situasi tertentu ketimbang mencoba menjelaskan hubungan atau penyebab dan akibat namun hal ini menyebabkan sebuah kebingungan karena desain penelitian deskriptif juga dapat digunakan dalam penelitian kuantitatif seperti menggunakan survey dimana data bisa di analisis secara numerikal.

\subsection{Metode Pengumpulan Data}

Pada metode ini, peneliti harus menentukan terlebih dahulu jenis data, sumber data dan teknik data yang digunakan dalam pengumpulan data.

\subsubsection{Jenis Data}

Jenis data yang digunakan :

1. Data Kualitatif

Menurut Huberman (2013), data kualitatif dengan penekanannya pada pengalaman orang-orang yang secara fundamental cocok untuk menempatkan arti dari sebuah tempat kejadian, proses, struktur dari kehidupan mereka dan untuk menghubungkan makna tersebut kepada dunia social yang ada disekitarnya.

\subsubsection{Sumber Data}

Ada dua sumber data dan metode pengumpulan data, antara lain:

1. Data Primer

Menurut Djahir (2014) data primer adalah data yang dikumpulkan secara langsung. Data primer yang digunakan penulis adalah wawancara yang berupa tanya jawab langsung dengan pihak yang terkait.

2. Data Sekunder

Menurut Djahir (2014), Data sekunder merupakan data yang dikumpulkan oleh orang lain atau pihak ketiga. Data sekunder umumnya berupa bukti, catatan atau laporan historis yang telah tersusun dalam arsip yang telah dipublikasikan.

\subsubsection{Teknik Pengumpulan Data}

Menurut Bakry (2016), pengumpulan data dalam penelitian untuk mendapatkan data primer dapat dilakukan dengan berbagai metode mulai dari metode wawancara, metode observasi, metode observasi berpartisipasi. Teknik pengumpulan data dalam penelitian ini adalah Metode wawancara dan Metode Observasi.

\subsection{Metode Analisis}

Penelitian ini merupakan penelitian yang bersifat deskriptif dengan tujuan untuk memberikan gambaran yang mendetail tentang latar belakang, sifat-sifat serta karakteristik yang khas dari subjek penelitian. Analisis ini dgunakan untuk membahas dan menerangkan 
hasil penelitian dengan menggunakan keterangan-keterangan yang tidak berbentuk angka. Dalam penelitian kualitatif, analisis data tidak harus menunggu selesainya pengumpulan data. Analisis data bersifat berkelanjutan dan dapat dikembangkan sepanjang penelitian.

\section{HASIL PENELITIAN DAN PEMBAHASAN}

\subsection{Hasil Penelitian}

Berdasarkan hasil penelitian yang didapat oleh peneliti, data yang diambil adalah status karyawan di CV Unggul Abadi terhadap pegawai tetap sebanyak 10 orang dan 24 orang tenaga harian lepas. Dalam melakukan perhitungan dan pemotongan Pajak Penghasilan Pasal 21 untuk karyawan tetap perusahaan dan tenaga harian lepas, peneliti terlebih dahulu mengumpulkan data mengenai pegawai tetap dan jenis-jenis penghasilan yang diterima karyawan diantaranya yaitu:

a. Data mengenai pegawai tetap dan Tenaga Harian Lepas

1. Pegawai tetap yang berjumlah 10 orang.

2. Upah harian yang diterima tenaga harian lepas dibayarkan secara bulanan berjumlah 24 orang.

b. Jenis Penghasilan yang diterapkan dalam perusahaan.

Hasil penelitian didalam untuk menentukan tujuan penelitian, dibagi kedalam beberapa tahap, yaitu :

\subsubsection{Inventarisasi Objek Pajak Penghasilan Pasal 21}

Perusahaan CV Unggul Abadi Manado dari segi operasional terdapat beberapa hal yang telah ditetapkan beberapa penghasilan yang dibayarkan kepada karyawan sebagaimana uraian berikut, yaitu:

1. Penghasilan yang bersifat teratur yang diterima secara bulanan, yaitu gaji pokok dan tunjangan - tunjangan lainnya.

2. Pembayaran penghasilan tidak teratur seperti THR dan uang lembur.

3. Pembayaran honorarium atau fee atas karyawan yang mengikuti pelatihan.

4. Pembayaran fee atas jasa service AC, Komputer dan pemeliharaan gedung kantor atau cleaning service.

\subsubsection{Perhitungan Pajak Penghasilan Pasal 21}

Berikut ini pada tabel 4.1 sampai 4.3 adalah perhitungan PPh Pasal 21 dari 3 sampel karyawan tetap kantor CV Unggul Abadi Manado berdasarkan perhitungan pada SPT Tahunan yang dilaporkan periode Januari - Desember 2016.

\section{Nama : Djauhari}

Tabel 4.1

Perhitungan PPh Pasal 21

\begin{tabular}{|l|r|}
\hline Penghasilan dan Pemotongan PPh Pasal 21 & Rupiah \\
$\begin{array}{l}\text { Penghasilan Bruto } \\
\text { Jumlah Penghasilan Bruto }\end{array}$ & Rp. 42.000.000 \\
$\begin{array}{l}\text { Pengurangan: } \\
\text { Biaya Jabatan } \\
\text { Jumlah Pengurangan }\end{array}$ & Rp. 2.100.000 \\
$\begin{array}{l}\text { Jumlah Penghasilan Neto } \\
\text { (Rp. 2.100.000) }\end{array}$ \\
\hline $\begin{array}{l}\text { Penghasilan Tidak Kena Pajak } \\
\text { Wajib Pajak Orang Pribadi }\end{array}$ & Rp. 600.000 \\
\hline Penghasilan Kena Pajak & (Rp. 27.600.000) \\
\hline
\end{tabular}

Sumber: Data SPT Tahunan Kantor CV Unggul Abadi Manado 2017 
Berdasarkan hasil perhitungan sebelumnya Pajak Penghasilan Pasal 21 diatas pada Tabel 4.1, dapat dilihat bahwa penghasilan Neto Bapak Djauhari sebesar Rp. 39.900.000,setahun adalah total seluruh penghasilan dan tunjangan yang dikurangi iuran wajib pegawai. Kemudian penghasilan tersebut dikurangi PTKP sehingga menghasilkan Penghasilan Kena Pajak (PKP).

Berikut ini Tabel 4.4 merupakan sampel pembayaran penghasilan tidak teratur, berupa uang lembur, upah harian tenaga lepas dan THR yang dibayarkan kepada pegawai di kantor CV. Unggul Abadi.

Tabel 4.4

Pembayaran Penghasilan Tidak Teratur

\begin{tabular}{|c|c|c|c|}
\hline No. & Nama Penghasilan & Jumlah & Keterangan Pembayaran \\
\hline 1 & Uang Lembur & Rp. 75.000,- & Setiap kali kegiatan lembur \\
\hline 2 & $\begin{array}{c}\text { Upah Tenaga Harian Lepas } \\
\text { (Tukang) }\end{array}$ & Rp. 150.000,- & Per hari kerja \\
\hline 3 & THR & Rp. 1.450.000,- & Setiap hari besar keagamaan \\
\hline \multicolumn{2}{|c|}{ Rp. 1.675.000,- } \\
\hline
\end{tabular}

Sumber: Data CV Unggul Abadi

Berikut adalah tabel 4.5 yang merupakan pembayaran penghasilan atas karyawan yang menerima honorarium dalam rangka mengikuti pelatihan untuk meningkatkan kinerja yang dibuat oleh Kantor CV Unggul Abadi.

Tabel 4.5

Pembayaran penghasilan atas Karyawan yang mengikuti Pelatihan

\begin{tabular}{|c|l|l|l|r|l|}
\hline No & Nama & Jabatan & Honor & PPh & $\begin{array}{c}\text { Jumlah Yang } \\
\text { Diterima }\end{array}$ \\
\hline 1 & Djauhari & Direktur & Rp. 1.000 .000 & - & Rp. 1.000 .000 \\
\hline
\end{tabular}

Sumber: Data CV Unggul Abadi

Diteliti lebih dalam, Kantor CV Unggul Abadi Manado juga membayarkan fee atas jasa service AC, Komputer dan pemeliharaan gedung kantor atau cleaning service.

\subsubsection{Pemotongan PPh Pasal 21}

Pemotong PPh Pasal 21 karyawan Kantor CV Unggul Abadi Manado dilakukan oleh Bendahara dan kemudian dilaporkan kepada KPPN, sehingga KPPN memotong langsung Pajak Penghasilan Pasal 21 pada penghasilan karyawan. Penghasilan yang dipotong tersebut kemudian disetorkan ke Kantor Perbendaharaan Negara (KPN) dan selanjutnya akan disetorkan ke rekening Direktorat Jenderal Pajak.

\subsubsection{Penyetoran dan Pelaporan PPh Pasal 21}

Setelah dilakukan perhitungan dengan benar oleh Bendahara Kantor selaku pembuat gaji sekaligus perhitungan besarnya Wajib Pajak yang telah dipotong dilampirkan pada Surat Setoran Pajak (SSP). Penyetoran SSP yang dilakukan Kantor CV Unggul Abadi disetorkan setiap tanggal 26 bulan taqwin atau satu hari setelah gaji dibayarkan. Penyetoran tersebut disetorkan ke Kantor Pos ataupun Bank.

\subsection{Pembahasan}

\subsubsection{Analisis Inventarisasi Objek Pajak Penghasilan Pasal 21}

Berdasarkan Peraturan Direktorat Jenderal Pajak Nomor: PER-16/PJ/2016 yaitu beberapa penghasilan yang dibayarkan kepada karyawan, berupa: 
1. Penghasilan yang bersifat teratur maupun tidak teratur yang diterima oleh pegawai tetap perusahaan.

2. Penghasilan yang diterima penerima pension secara teratur.

3. Penghasilan berupa uang pesangon yang pembayarannya melewati jangka waktu 2 tahun sejak pegawai berhenti bekerja.

Setelah ditelusuri, adapun penghasilan yang telah perusahaan tetapkan untuk dibayarkan kepada karyawan CV Unggul Abadi sebagaimana uraian berikut, yaitu:

1. Penghasilan yang bersifat teratur yang diterima secara bulanan, yaitu gaji pokok dan tunjangan - tunjangan lainnya.

2. Pembayaran penghasilan tidak teratur seperti THR dan uang lembur.

3. Pembayaran honorarium atau fee atas karyawan yang mengikuti pelatihan.

4. Pembayaran fee atas jasa service AC, Komputer dan pemeliharaan gedung kantor atau cleaning service.

Setelah didalami lebih lanjut, dalam pengelompokkan penghasilan yang diterapkan dalam perusahaan, pembayaran penghasilan tersebut digolongkan kedalam Objek PPh Pasal 21, yaitu:

1. Penghasilan yang bersifat teratur yang diterima secara bulanan, yaitu gaji pokok dan tunjangan - tunjangan lainnya. Tunjangan tersebut antara lain tunjangan makan, transportasi, jabatan dan tunjangan lainnya.

2. Perusahaan CV Unggul Abadi Manado juga menerapkan pembayaran penghasilan tidak teratur seperti THR dan uang lembur. Uang lembur dihitung berdasarkan jumlah jam kerja yaitu Rp. 75.000,- per lembur dan upah yang dibayarkan untuk Tenaga Harian Lepas berjumlah Rp. 150.000,- per hari.

3. Perusahaan juga membayarkan honorarium atau fee atas karyawan yang mengikuti pelatihan dalam rangka meningkatkan kualitas kinerja karyawan sesuai yang telah ditetapkan.

4. Pembayaran penghasilan atas fee jasa service AC, Komputer dan pemeliharaan gedung kantor atau cleaning service.

Objek PPh Pasal 21 yang diterapkan dalam Kantor CV Unggul Abadi Manado memang merupakan objek PPh Pasal 21 yaitu penghasilan yang diterima atau diperoleh pegawai tetap, baik berupa penghasilan yang bersifat teratur yaitu gaji bulanan, tunjangan anak dan istri, tunjangan struktural/jabatan, tunjangan beras, tunjangan khusus dan tunjangan lain-lain serta penghasilan yang bersifat tidak teratur yaitu THR ataupun uang lembur yang bersifat tidak final sesuai dengan ketetapan Peraturan Direktur Jenderal Pajak PER16/PJ/2016. Objek Pajak Penghasilan 21 yang diterapkan tersebut telah dilakukan pemungutan dengan tarif progresif yang berlaku.

Namun dari hasil analisis terhadap inventarisasi objek PPh Pasal 21, ada beberapa yang harusnya diterapkan berdasarkan PER-16/PJ/2016 yaitu berupa:

1. Penghasilan yang diterima penerima pension secara teratur.

2. Penghasilan berupa uang pesangon yang pembayarannya melewati jangka waktu 2 tahun sejak pegawai berhenti bekerja.

3. Penghasilan berupa honorarium yang diterima oleh anggota dewan komisaris yang tidak merangkap sebagai pegawai tetap pada perusahaan yang sama.

4. Penghasilan berupa jasa produksi, bonus atau imbalan lainnya yang diterima mantan pegawai.

5. Penghasilan berupa tarikan dana pension oleh peserta program pensuin yang berstatus sebagai pegawai, yang telah disahkan oleh Menteri Keuangan.

Dari hasil wawancara, tidak dilakukannya pemungutan atas kelima poin objek $\mathrm{PPh}$ Pasal 21 diatas dikarenakan ketidaktahuan mengenai poin-poin tersebut apakah berkaitan dengan PPh 21 atau tidak. Kemudian, disarankan untuk kedepannya terlebih khusus untuk 
kelima poin objek PPh Pasal 21 yang belum dipungut dalam Kantor CV Unggul Abadi tersebut akan disarankan untuk dilakukan pemungutan, hal itu dikarenakan akan terus berdampak dalam pelaporan dan kepatuhan wajib pajak perihal objek PPh Pasal 21 yang harusnya diterapkan dalam suatu perusahaan terhadap pendapatan pajak Negara. Adapun sanksi yang akan didapatkan oleh perusahaan apabila Objek tersebut tidak diterapkan, yaitu mendapat sorotan dan teguran dari Direktorat Jenderal Pajak.

\subsubsection{Analisis Perhitungan Pajak Penghasilan Pasal 21}

Dalam menghitung PPh Pasal 21 atas karyawan, terlebih dahulu dihitung seluruh penghasilan bruto yang diterima atau diperoleh karyawan Kantor CV Unggul Abadi selama sebulan meliputi gaji, segala jenis tunjangan dan pembayaran lainnya termasuk uang lembur dan sejenisnya.

Selanjutnya dihitung jumlah penghasilan netto sebulan yang diperoleh dengan cara mengurangi seluruh penghasilan bruto sebulan dengan biaya jabatan kemudian iuran pensiun yang harus dibayarkan sendiri oleh pegawai yang bersangkutan melalui pemberi kerja yang telah disahkan oleh Menteri Keuangan. Status kawin karyawan juga memepengaruhi besranya Jumlah Penghasilan Tidak Kena Pajak (PTKP). Status kawin karyawan tersebut berupa status belum kawin (TK), kawin dengan anak satu (K/1), kawin dengan anak dua $(\mathrm{K} / 2)$ dan yang terakhir kawin dengan anak tiga $(\mathrm{K} / 3)$. Berdasarkan status kawin dan jumlah tanggungan karyawan berdasarkan rincian diatas maka perhitungan PTKP masing-masing karyawan adalah sebagai berikut :

Tabel 4.6

Perhitungan PTKP

\begin{tabular}{|c|c|c|c|c|}
\hline No. & Status & PTKP/Tahun & PTKP/Bulan & Keterangan \\
\hline 1 & TK & Rp. 54.000.000 & Rp. 4.500.000 & WPOP tidak menikah \\
\hline 2 & K/1 & Rp. 63.000.000 & Rp. 5.250.000 & $\begin{array}{c}\text { WPOP menikah dengan 1 } \\
\text { tanggungan anak }\end{array}$ \\
\hline 3 & K/2 & Rp. 67.500.000 & Rp. 5.625.000 & $\begin{array}{c}\text { WPOP menikah dengan 2 } \\
\text { tanggungan anak }\end{array}$ \\
\hline 4 & K/3 & Rp. 72.000.000 & Rp. 6.000.000 & $\begin{array}{c}\text { WPOP menikah dengan 3 } \\
\text { tanggungan anak }\end{array}$ \\
\hline
\end{tabular}

Tabel diatas menunjukkan perhitungan PTKP karyawan berdasarkan status. Berikut akan diuraikan lebih rinci perhitungan PPh Pasal 21, yaitu Tarif PPh Pasal 21 menurut ketentuan Undang-Undang Perpajakan, WP dengan penghasilan tahunan :

a. Sampai dengan Rp. 50.000.000,- dikenakan tarif 5\%

b. Penghasilan tahunan diatas Rp. 50.000.000,- s/d Rp. 250.000.000,- dikenakan tarif $15 \%$

c. Penghasilan tahunan diatas Rp. 250.000.000,- s/d Rp. 500.000.000,- dikenakan tarif $25 \%$

d. Penghasilan tahunan diatas Rp. 500.000.000,- dikenakan tarif 30\%.

Dikecualikan bagi penerima penghasilan yang dipotong PPh Pasal 21 untuk Wajib Pajak yang tidak memiliki Nomor Peserta Wajib Pajak (NPWP), akan dikenakan tarif PPh Pasal 21 sebesar 20\% daripada tarif yang dikenakan terhadap WP yang memiliki NPWP. Artinya jumlah PPh Pasal 21 yang harus dipotong adalah 120\% dari jumlah PPh Pasal 21 yang seharusnya dipotong dalam hal yang bersangkutan memiliki NPWP. Pemotongan PPh Pasal 21 seperti ini hanya berlaku untuk pemotongan PPh Pasal 21 yang bersifat tidak final.

Setelah diperoleh $\mathrm{PPh}$ terutang dengan menerapkan tarif pasal $17 \mathrm{UU} \mathrm{PPh}$ terhadap Penghasilan Kena Pajak (PKP), selanjutnya dihitung PPh Pasal 21 per bulan yang harus dipotong dan atau disetorkan ke kas negara, yaitu : 
a. Jumlah PPh Pasal 21 setahun dibahagi dengan 12 bulan; atau

b. Jumlah PPh Pasal 21 setahun dibahagi banyaknya bulan yang menjadi faktor penggali dalam hal wajib pajak.

Berdasarkan perhitungan SPT Tahunan, Kantor CV Unggul Abadi telah menetapkan dan melakukan perhitungan Pajak Penghasilan Pasal 21 sesuai dengan Undang-Undang Perpajakan. Dalam hal ini menggunakan pedoman Peraturan Direktur Jenderal Pajak No. PER-16/PJ/2016. Perhitungan PPh Pasal 21 yang akan dibahas lebih lanjut sesuai dengan SPT Tahunan bagi pegawai dengan Status kawin karyawan berupa status belum kawin (TK), kawin dengan anak satu (K/1), kawin dengan anak dua $(\mathrm{K} / 2)$ dan yang terakhir kawin dengan anak tiga (K/3). Berikut ini adalah perhitungan PPh Pasal 21 dari sampel 3 karyawan Kantor CV Unggul Abadi Manado.

Berdasarkan hasil perhitungan pada tabel 4.1 SPT Tahunan atas nama Bapak Djauhari, dapat dilihat bahwa penghasilan neto Djauhari sebesar Rp. 39.900.000,- setahun sudah sesuai dengan Peraturan Direktur Jenderal Pajak No. PER-16/PJ/2016 dalam hal ini objek PPh Pasal 21 berupa gaji pokok dan tunjangan. Namun ditemukan, Bapak Djauhari belum dapat dikenakan Pajak Penghasilan Pasal 21 karena dalam penerapan Dasar Pengenaan Pajak (DPP) dianggap belum memenuhi kriteria seperti yang diatur dalam Peraturan Direktur Jenderal Pajak No. PER-16/PJ/2016 yaitu sebesar Rp. 54.000.000,- selama setahun.

Selanjutnya pada tabel 4.2 SPT Tahunan atas nama Ibu Shihanne Marentek, disimpulkan bahwa penghasilan neto yang bersangkutan sudah sesuai dengan peraturan yang berlaku yaitu sebesar Rp. 30.400.000,- . Namun hal yang sama terjadi seperti Bapak Djauhari yaitu penghasilan Ibu Shihanne belum dapat dikenakan Pajak Penghasilan Pasal 21 karena belum memenuhi kriteria jumlah penghasilan.

Berdasarkan hasil perhitungan pada tabel 4.3 SPT Tahunan atas nama Bapak Adhi Bara Nyoto Putro disimpulkan bahwa jumlah penghasilan neto yang bersangkutan sebesar Rp. 50.350.000,- setahun berjalan sudah sesuai dengan peraturan Direktur Jenderal Pajak Nomor PER-16/PJ/2016 dalam hal objek pajak berupa gaji pokok dan tunjangan telah memenuhi kriteria sebesar Rp.50.000.000 dikenakan tarif pajak 5\% sesuai ketentuan, sehingga didapatkan perhitungan jumlah Penghasilan Kena Pajak dikalikan dengan 5\% dan hasilnya sebesar Rp. 5.350.000,-.

Menurut Peraturan Direktorat Jenderal Pajak Nomor: PER-16/PJ/2016 juga mengatur tentang Objek Pajak Penghasilan Pasal 21 berupa upah harian, upah mingguan, upah satuan, upah borongan atau upah yang dibayarkan secara bulanan kepada karyawan. Namun terhadap objek PPh Pasal 21 berdasarkan tabel 4.4 penghasilan yang tidak teratur tidak dikenakan Pemotongan PPh Pasal 21 atas objek tersebut yang seharusnya dikenakan tarif progresif. Berdasarkan PER-16/PJ/2016 pasal 9 ayat 1 yaitu jumlah kumulatif yang diterima sebulan melebihi Rp. 4.500.000,-. Alasan pihak Kantor CV Unggul Abadi tidak memunggut PPh Pasal 21 untuk pembayaran penghasilan tidak teratur dikarenakan jumlah kumulatif penghasilan yang diterima berbeda per kayawannya, dan hampir semua tidak mencapai pada jumlah kumulatif berdasarkan peraturan tersebut.

Berdasarkan Peraturan Menteri Keuangan tentang PTKP 2016, PPh Pasal 21 pegawai tidak tetap atau tenaga kerja lepas yang penghasilannya kurang dari Rp 450.000 per hari tidak dikenakan pemotongan penghasilan, yaitu:

1. Penghasilan yang kurang dari 450.000 ,- per hari tidak dikenakan pemotongan pajak penghasilan.

2. Ketentuan penghasilan tidak kena pajak itu tidak berlaku dalam hal:

1. Penghasilan bruto dimaksud jumlahnya melebihi Rp 4.500.000,- sebulan; atau

2. Penghasilan dimaksud dibayar secara bulanan

Ketentuan pada pasal 1 dan 2 tersebut tidak berlaku atas:

a. Penghasilan berupa honorarium 
b. Komisi yang dibayarkan kepada penjaga barang dan petugas dinas luar asuransi.

Apabila seiring berjalannya kinerja dalam Kantor CV Unggul Abadi, ditemukan penghasilan tidak teratur karyawan melebihi jumlah kumulatif Rp. 4.500.000,- maka rumusan perhitungan PPh Pasal 21, yaitu sebagai berikut:

Tabel 4.7

Dasar Pengenaan Pajak (DPP) yang dikenakan pada karyawan tidak tetap

\begin{tabular}{|c|c|c|c|}
\hline No. & Penghasilan Sehari & $\begin{array}{c}\text { Penghasilan Kumulatif } \\
\text { Sebulan }\end{array}$ & Tarif dan DPP \\
\hline 1 & $>$ Rp. 450.000,- & $<$ Rp. 4.500.000,- & Tidak ada tarif PPh Pasal 21 \\
\hline 2 & $<$ Rp. 450.000,- & < Rp. 4.500.000,- & $5 \%$ x (Upah - Rp. 450.000,- \\
\hline 3 & $>$ Rp. 450.000,- & $>$ Rp.4.500.000,- & $5 \%$ x (Upah - (PTKP/360)) \\
\hline 4 & $\begin{array}{c}\text { < Rp. 450.000,- } 450.000,- \\
\text { < Rp. 450.000,- }\end{array}$ & $>$ Rp. 10.200.000,- & $\begin{array}{c}\text { Tarif pada Undang-Undang } \\
\text { Pajak Penghasilan Pasal 17 } \\
\text { ayat (1) huruf (a) }\end{array}$ \\
\hline
\end{tabular}

Berdasarkan hasil penelitian pada tabel 4.5 yang telah dibahas sebelumnya, dengan tidak dipungutnya penghasilan atas honorarium yang diberikan kepada pegawai atau karyawan yang mengikuti pelatihan dalam rangka meningkatkan kualitas kinerja belum sesuai dengan peraturan pajak yang berlaku karena dalam hal ini, Kantor CV Unggul Abadi tidak memotong PPh Pasal 21 kepada pegawai tersebut sebagaimana yang diatur dalam Peraturan Direktur Jenderal Pajak PER-32/PJ/2015 Pada Pasal 1 nomor (13) yaitu orang pribadi yang terlibat dalam suatu kegiatan tertentu, termasuk mengikuti rapat, sidang, seminar, lokakarya, pendidikan, pertunjukan, olahraga, atau kegiatan lainnya dan menerima atau memperoleh imbalan sehubungan dengan keikutsertaannya dalam kegiatan tersebut. Sejalan dengan itu, Pasal 5 ayat 1 huruf (f) pada PER-32/PJ/2015 juga menyatakan bahwa penghasilan yang dipotong PPh Pasal 21 adalah imbalan kepada peserta kegiatan, antara lain berupa uang saku, uang representasi, uang rapat, uang honorarium, hadiah ataupun penghargaan dengan nama dalam bentuk apapun, dan imbalan sejenis dengan nama apapun. Terhadap objek PPh Pasal 21 tersebut, tidak dilakukan pemungutan dengan tarif yang ditentukan oleh Peraturan Direktur Jenderal Pajak PER-32/PJ/2015.

Berikut perhitungan PPh Pasal 21 atas penghasilan yang diterima oleh karyawan yang mengikuti Kegiatan Pelatihan:

Tabel 4.8

Perhitungan PPh Pasal 21 atas Karyawan yang mengikuti Pelatihan PPh Pasal 21 = Penghasilan Bruto x Tarif PPh Pasal 17

Setelah ditelusuri kembali, alasan yang didapat adalah Bendahara belum memahami lebih dalam tentang objek PPh Pasal 21 sehingga terjadi kekeliruan dengan tidak dipungutnya PPh Pasal 21 atas karyawan tersebut. Kantor CV Unggul Abadi Manado hanya memungut PPh Pasal 21 atas objek-objek yang telah dijabarkan diatas, akan tetapi terdapat juga beberapa penghasilan yang merupakan objek Pajak Penghasilan Pasal 21 yang seharusnya dipungut tetapi tidak dipungut oleh Kantor CV Unggul Abadi Manado.

Kantor CV Unggul Abadi Manado juga membayarkan fee atas jasa servis AC, Komputer dan Pemeliharaan Gedung dan membayarkan gaji cleaning service namun ditemukan lagi tidak dipungut PPh Pasal 21 atas penghasilan-penghasilan tersebut. Jasa servis AC dan Komputer yang dibayarkan adalah sebesar Rp. 1.000.000,- setiap servis di Kantor CV Unggul Abadi Manado. Ditemukan pada tahun 2016 dan 2017, Kantor CV Unggul Abadi 
Manado memakai jasa servis AC dan Komputer selama 3x. Jasa pemeliharaan gedung yang dibayarkan yaitu tergantung pada berapa besar kerusakan yang terjadi pada gedung Kantor CV Unggul Abadi Manado. Total pemeliharaan Inventaris dan gedung kantor pada tahun 2016 sampai akhir 2017 sebesar Rp. 8.000.000,- . yang terakhir pembayaran gaji cleaning service dibayarkan setiap bulan sebesar Rp. 2.100.000,-.

Berdasarkan peraturan Direktur Jenderal Pajak PER-16/PJ/2016 pasal 3 huruf (c) yaitu merupakan penerimaan penghasilan yang dipotong PPh Pasal 21 yaitu atas pemberi jasa dalam segala bidang termasuk teknik, komputer dan sistem aplikasi, telekomunikasi, elektronik, fotografi, ekonomi dan sosial serta pemberi jasa kepada suatu kepanitiaan. Dengan demikian penghasilan yang diterima, oleh pemberi jasa tersebut masuk dalam objek Pajak Penghasilan Pasal 21.

Oleh karena itu, pembayaran fee atas jasa servis AC dan Komputer merupakan objek PPh Pasal 21 dengan Dasar Pengenaan Pajak menurut PER-16/PJ/2016 yaitu 50\% (lima puluh persen) dari jumlah penghasilan bruto. Setelah diwawancarai lebih dalam, terdapat alasan dari pihak Kantor CV Unggul Abadi yaitu dengan tidak dipungutnya PPh Pasal 21 atas penghasilan tersebut dikarenakan ketidaktahuan Bendahara kantor mengenai peraturan perpajakan yang berlaku atas jasa servis AC dan Komputer pada Kantor CV Unggul Abadi Manado dan didapati pembayaran atas jasa pemeliharaan gedung kantor dan jasa cleaning service belum dikenakan PPh Pasal 21 oleh Kantor CV Unggul Abadi Manado karena tidak memenuhi kriteria Dasar Pengenaan Pajak yang berlaku.

Dari hasil pembahasan yang peneliti jabarkan, kesimpulan sementara yang dapat ditarik dari Kantor CV Unggul Abadi Manado masih terdapat objek PPh Pasal 21 yang sudah dipungut dan sesuai peraturan yang berlaku, dan adapun yang belum dipungut karena ketidaktahuan bendahara kantor selaku pihak pemotong pajak penghasilan pasal 21 .

\subsubsection{Analisis Pemotongan PPh Pasal 21}

Pemotong PPh Pasal 21 karyawan Kantor CV Unggul Abadi Manado dilakukan oleh Bendahara dan kemudian dilaporkan kepada KPPN, sehingga KPPN memotong langsung Pajak Penghasilan Pasal 21 pada penghasilan karyawan. Penghasilan yang dipotong tersebut kemudian disetorkan ke Kantor Perbendaharaan Negara (KPN) dan selanjutnya akan disetorkan ke rekening Direktorat Jenderal Pajak.

KPN membayar setoran pajak setiap bulan pada tanggal 10 bulan berikutnya, misalnya setoran pajak bulan Oktober 2016 dibayarkan pada tanggal 10 bulan November 2016.

\subsubsection{Analisis Penyetoran dan Pelaporan PPh Pasal 21}

Setelah dilakukan perhitungan dengan benar oleh Bendahara Kantor selaku pembuat gaji sekaligus perhitungan besarnya Wajib Pajak yang telah dipotong dilampirkan pada Surat Setoran Pajak (SSP). Penyetoran SSP yang dilakukan Kantor CV Unggul Abadi disetorkan setiap tanggal 26 bulan taqwin atau satu hari setelah gaji dibayarkan. Penyetoran tersebut disetorkan ke Kantor Pos ataupun Bank. Selanjutnya pihak Kantor Pos atau Bank akan memberikan bukti pelunasan setoran PPh Pasal 21 kepada setiap wajib pajak disertai Nomor Transaksi Penerimaan Negara (NTPN). Setiap wajib pajak yang melalukan pembayaran PPh Pasal 21 ke Bank atau kantor Pos harus mendapatkan NTPN. NTPN harus di isi dalam SPT $\mathrm{PPh}$ Pasal 21 sebagai bukti pembayaran pajak yang sah.

Dari penyetoran PPh Pasal 21 Kantor CV Unggul Abadi, SSP dilaporkan ke Kantor Pelayanan Pajak (KPP) beserta SPT Tahunan Pajak Penghasilan Pasal 21 yang telah diisi dengan benar, lengkap dan jelas. Pelaporan SPT Tahunan PPh Pasal 21 harus dilaporkan selambat-lambatnya tanggal 31 bulan berjalan ke Kantor Pelayanan Pajak. Setelah melaporkan SPT Tahunan tersebut CV Unggul Abadi akan mendapatkan bukti penerimaan Surat dari Kantor Pelayanan Pajak yang dapat digunakan sebagai dasar bahwa CV Unggul Abadi telah memenuhi kewajiban perpajakan sesuai dengan peraturan perpajakan yang 
berlaku saat ini dan kemudian di arsipkan bersama dokumen-dokumen penting kantor $\mathrm{CV}$ Unggul Abadi.

Batas waktu pelaporan dan penyetoran PPh Pasal 21 adalah tanggal 10 bulan berikutnya menurut ketentuan Undang-Undang Perpajakan.

\section{KESIMPULAN DAN SARAN}

\subsection{Kesimpulan}

Berdasarkan hasil analisis pada bagian sebelumnya, dapat disimpulkan bahwa:

1. Berdasarkan ketentuan Objek PPh Pasal 21 menurut PER-16/PJ/2016, masih terdapat objek PPh Pasal 21 yang belum dipungut oleh Kantor CV Unggul Abadi Manado yaitu penghasilan atas karyawan yang mengikuti pelatihan, fee atas jasa servis AC, dan pemeliharaan gedung kantor dan gaji Cleaning Service.

2. Dari segi perhitungan Pajak Penghasilan Pasal 21 yang dilakukan oleh Kantor CV Unggul Abadi Manado telah sesuai dengan aturan perundang-undangan perpajakan terbaru yakni Peraturan Direktur Jenderal Pajak Nomor PER16/PJ/2016 untuk perhitungan PPh Pasal 21 khususnya perhitungan pada SPT Tahunan.

3. Dari segi penyetoran dan pelaporan SPT karyawan Kantor CV Unggul Abadi Manado dilakukan oleh Kantor Perbendaharaan Negara (KPN) melalui proses manual dan belum menggunakan pelaporan secara online atau elektronik melalui website namun tetap sesuai dengan ketentuan yang berlaku.

\subsection{Saran}

Berdasarkan dari kesimpulan sebelumnya, maka saran yang dapat peneliti berikan untuk Kantor CV Unggul Abadi Manado adalah sebagai berikut :

1. Disarankan untuk merekrut kembali pegawai yang cakap dan ahli dalam memahami tatacara perhitungan, penyetoran serta pelaporan Pajak Penghasilan Pasal 21, sehingga Kantor CV Unggul Abadi akan lebih memahami pemungutan pajak yang berlaku dan tidak akan melakukan keliruan lagi dalam hal pelaporan pajak sesuai peraturan yang berlaku.

2. Sering mengikuti kegiatan-kegiatan yang berhubungan dengan perpajakan dan menggali informasi lebih dalam mengenai peraturan perpajakan terbaru terlebih khusus menyangkut Pajak Penghasilan Pasal 21 dan Pajak yang berlaku dalam Kantor CV Unggul Abadi Manado.

3. Terus meng-update sistem terbaru penunjang dalam proses perhitungan sampai pada penyetoran dan pelaporan SPT PPh Pasal 21.

\section{DAFTAR PUSTAKA}

Asmani, J.M, 2011. Tuntunan Lengkap Metodologis Praktis Penelitian Pendidikan. Diva Press, Jakarta

Brontodiharjo, R. Santoso, 2011. Pengantar Ilmu Hukum Pajak. Adika, Bandung

Harnanto. 2013. Perencanaan Pajak. Edisi Pertama. Cetakan Kedua. BPFE. Yogyakarta.

Mardiasmo, 2016. Perpajakan Edisi Revisi. Andi, Yogyakarta

Muljono. 2010. Hukum Pajak-Konsep, Aplikasi dan Penentuan Praktis. Andi, Yogyakarta.

Peraturan Direktur Jenderal Pajak Nomor PER-32/PJ/2015 tentang pedoman Teknis Cara Pemotongan, Peyetoran dan Pelaporan Pajak Penghasilan Pasal 21 Sehubungan dengan Jasa, Pekerjaan dan Kegiatan Orang Pribadi.

Peraturan Direktur Jenderal Pajak Nomor PER-16/PJ/2016 tentang pedoman Teknis Cara Pemotongan, Peyetoran dan Pelaporan Pajak Penghasilan Pasal 21 dan/atau Pajak 
Penghasilan Pasal 26 Sehubungan Dengan Pekerjaan, Jasa dan Kegiatan Orang Pribadi

Rahman Arif, 2013. Panduan Akuntansi dan Perpajakan. Transmedia, Jakarta.

Republik Indonesia, 2008. Undang-Undang Nomor 7 Tahun 1983 sebagaimana yang telah diubah dengan Undang-Undang Nomor 36 Tahun 2008 Tentang Pajak Penghasilan.

Republik Indonesia, 2007. Undang-Undang Nomor28 Tahun 2007tentang Ketentuan Umum dan Tatacara Perpajakan

Sadeli, M. Lili. 2010. Dasar-Dasar Akuntansi. PT. Bumi Aksara, Jakarta.

Sonya Lasmana, Mienati dan Budi Setiorahardjo, 2012. Cara Perhitungan Pemotongan PPh Pasal 21. Graha Ilmu, Yogyakarta

V. Wiratna Sujarweni, 2014. Metodologi Penelitian. Pustaka Baru Press, Yogyakarta.

Waluyo, 2013. Perpajakan Indonesia. Buku Pertama Edisi 11. Salemba Empat, Yogyakarta

Woro Damayanti, 2010. Perpajakan Indonesia - mekanisme dan perhitungan. CV Andi

Offset, Yogyakarta 